\title{
Grammatical polysemy and grammaticalization in cognitive and generative perspectives: Finding common ground in inter- generational corpora of ancient languages ${ }^{1}$
}

\author{
Christian Locatell \\ Institute of Archaeology and the Department of Land of Israel Studies and Archaeology, Ariel University, Israel \\ Department of Ancient Studies, Stellenbosch University, South Africa \\ E-mail: christiano.locatell@gmail.com
}

\begin{abstract}
Cognitive and generative approaches to linguistics have taken a different perspective on grammatical polysemy and grammaticalization. While the former see polysemy as a core characteristic of language and a necessary result of grammaticalization within idiolects, the latter see it as a less interesting phenomenon peripheral to linguistics proper. Grammaticalization is seen as a phenomenon of language acquisition which does not disturb the homogeneity of idiolects. These differing perspectives have generated much debate between the two approaches and are even in large part responsible for the different programmatic focuses of each. While the disagreement over grammatical polysemy between these two approaches to language is rooted in entrenched commitments on each side that are perhaps irreconcilable, at least some common ground does seem to be possible. Specifically, when it comes to intergenerational corpora, it seems that both cognitive and generative approaches to linguistics can agree that the universal phenomenon of grammaticalization would result in polysemy at least at the language community level. This can serve as a common ground on which both generative and cognitive linguists can join efforts in describing and explaining usage profiles of grammatically polysemous forms at the corpus level according to prototypicality, even if disagreement persists on the nature of the idiolect. ${ }^{2}$
\end{abstract}

Keywords: polysemy, polyfunctionality, grammaticalization, cognitive linguistics, generative linguistics, corpus linguistics, ancient languages

\footnotetext{
${ }^{1}$ Subsidy for this research is given by the Israeli Science Foundation, grant no. 674/15 at Ariel University (PI: Shai Gordin) and grant no. 522/16 at Ariel University (PI: Itzhaq Shai).

${ }^{2}$ As a short biographical note about Dr. Oosthuizen, for whom this honorary volume has been prepared, I have been tremendously grateful for the collaborative spirit he has shown between the generative and more functional (especially cognitive) approaches to language. I have benefitted much from participation in discussions and various collaborative efforts between the Ancient Studies Department and the General Linguistics Department at Stellenbosch University on many topics, from left-dislocation, to conjunctions, serial verb constructions, and others. Thus, at the intersection of generative linguistics, cognitive linguistics, and ancient languages, this paper is a fitting contribution for the occasion.
} 


\section{Introduction}

Grammatical polysemy refers to grammatical forms that are used in multiple ways. This is a less well-known aspect of linguistic inquiry, but constitutes the focus of one of four basic research questions in linguistics - namely, how do people use a grammatical construction (Glynn 2010: 18-19)? ${ }^{3}$ Grammatical polysemy appears to pose a particular difficulty for compatibility between generative and cognitive linguistics since it cannot simply be quarantined within the lexicon (as with lexical polysemy) and does not enjoy the uncontroversial status of the fact that a concrete concept may be referred to in multiple ways (lexical synonymy) or that a schematic grammatical relationship may be realized in multiple constructions (grammatical synonymy, e.g. "I like a good run/to run/running" where a noun phrase, infinitive, or gerund can be the direct object of a verb). ${ }^{4}$

An example of this phenomenon can be seen in the polysemy of the English adverbial conjunction since which may be temporal or causal, seen in example (1) below from Haug (2008: 289-290; cf. Kortmann 1997: 90-91).
a. $\quad$ Since Susan left him, John has been very miserable.
b. In fact, he has been miserable ever since he first met her.
c. Since you are not coming with me, I will have to go alone.

In (1), the temporal meaning is present with an invited causal inference, since a causal link would make the relationship between the two clauses more relevant. This causal implicature could be cancelled with the second utterance in (1). However, there are also uses of causal since which have a non-cancellable causal meaning, as in (1), which has no temporal meaning at all, since that would require the since-clause to be in a past tense. In some linguistic circles, this is taken as evidence that words like since are polysemous within the morphosyntactic category of adverbial conjunction.

A related phenomenon termed heterosymy, sometimes subsumed under polysemy, obtains when a particular form belongs to multiple morphosyntactic categories (Lichtenberk 1991). For instance, Kortmann (1997: 58-59) points to English for as in example (2) as an illustration of one word belonging to multiple word classes (cf. Kortmann 1998: 458).

(2) a. John did not reply, for he knew he was wrong.

b. We are hoping for John to improve himself.

c. The present was for Mary.

We can see here that for is a causal conjunction as in (2), a verbal complementizer as in (2), and a preposition as in (2). The comments I will make here apply equally to both phenomena, and so for simplicity sake, I will simply refer to these as polysemy.

\footnotetext{
${ }^{3}$ The other three being: What words do people choose for a given concept (lexical synonymy)? What grammatical constructions do people use for a given schematic representation (grammatical synonymy)? And, in what different ways do people use a given word (lexical polysemy)? Glynn (2010: 19).

${ }^{4}$ Of course, idioms are perhaps one of the clearest phenomena that challenge a sharp distinction between the grammar and the lexicon (Wulff 2010: 225). The comments made here are compatible with the view that the lexicon and grammar form a continuum and that the nature of one is fundamentally the same as the other, the difference being that the former is less schematic and the latter more (cf. Evans 2014: 247).
} 
The analysis of such phenomena has divided linguists coming from cognitive and generative approaches. On the one hand, cognitive linguistics sees such polysemy as fundamental to the very nature of language itself due to its emergent, usage-based character. On the other hand, generative linguistics sees the grammar of an individual speaker as static and homogenous. Any grammatical variation is attributed to a new setting of parameters in the process of language acquisition between generations. These diverging commitments have led to entrenched positions and the impression that compatibility between these two approaches is as likely as water and oil mixing. The purpose of this paper is to suggest an inviting playing field where the disjointed ground between these models becomes more aligned and uneven patches are leveled out - namely, intergenerational corpora of ancient languages, using the Hebrew Bible as an illustration. In this space, both cognitive and generative models lead to the conclusion that grammatical forms are emergent, polysemous, and structured according to prototypicality at the corpus level. In order to do this, I will first briefly sketch the basic generative and cognitive models of polysemy and grammaticalization in sections 2 and 3 respectively. Then in section 4 I will explain why the common disputes between proponents of these competing theories do not apply so much to those working on grammatical analyses of ancient languages based on multi-generational corpora. This will include a brief example from the debate surrounding the grammatical description of the Hebrew verbal system, before concluding in section 5.

\section{Generative and cognitive perspectives on grammatical polysemy ${ }^{5}$}

According to the famous Chomskyan dictum, "Linguistic theory is concerned primarily with an ideal speaker-listener, in a completely homogeneous speech-community, who knows its language perfectly..." (Chomsky 1965: 3). From this perspective, variation of use is either a matter of performance (to be hedged off from speaker competence in the linguistic system as the primary subject of linguistic inquiry) or a matter of intergenerational shift in the values assigned to certain parameters (in which case it is a question of language acquisition, see Roberts and Roussou 2003: 11 and Van Gelderen 2011: 50-55, more on this below). A third option would be to see variation of use as purely pragmatic and therefore distinct from grammar as the primary object of linguistic investigation. Thus, going back to Meillet's characterization of "langue" as "un système où tout se tient", Fischer (2007: 54) quips that structuralist and generative approaches are schools of thought in which "the system of grammar became more important as an object of study than the actual language data." She goes on to note: "In such a system, idiosyncrasies, fuzziness, and variation have no place... They are therefore relegated to the lexicon and to the performance level" (ibid: 63; cf Weinreich et al. 1968: 150). Framed in this way, the grammatical polysemy that characterizes linguistic performance becomes a less interesting and more peripheral issue. It may be thought of more or less as background noise to be filtered out from the clear picture of the linguistic system. ${ }^{6}$

Alternatively, grammatical polysemy is seen to be an essential part of language from the perspective of cognitive linguistics (Heine et al. 1991: 260; Nerlich and Clarke 2003: 5). For example, Kortmann (1997: 14) see the (post-) Sausserian tenant of isomorphism as something from which to be emancipated. The basic reason for this is that, from a cognitive perspective,

\footnotetext{
${ }^{5}$ In this paper, I compare a broadly generative approach to these issues with a cognitive linguistic perspective. However, much of the description of the cognitive approach also applies to approaches more broadly characterized by a functional, usage-based perspective on language.

${ }^{6}$ As Fischer (2007: 66) explains: "Within the generative school, the study of the language output has been relegated to the lowest possible position."
} 
grammar is seen as usage-based and therefore always emergent and dynamic rather than static and homogenous (Hopper 1987, 2012). One phenomenon from which language's emergent character is argued to be seen especially clearly is in the process of grammaticalization in which erstwhile lexical forms become grammatical, or grammatical forms acquire different grammatical functions (Hopper and Traugott 2003: 1). When older uses persist alongside newer ones in the process of change (called 'layering'), the inescapable result is polysemy (Bybee et al. 1994: 15-16, 300; Bybee 2003: 150-151; Hopper and Traugott 2003: 124; Traugott 2010: 38; Ramat and Mauri 2011). As stated by Traugott (2012: 551), “...without polysemy one cannot account for the fine-grained step-by-step developments that are attested by detailed study of texts and contexts over time" (cf. Geeraerts 2010: 42; Esseesy 2010: 51-52). Thus, according to cognitive linguistics, polysemy is an essential part of language and inescapable product of gradual change.

Generative linguistics of course acknowledges the phenomenon of language change in which certain grammatical forms evolve into different morphosyntactic categories. As Faarlund (2008: 221) comments: "the data which grammaticalizationists describe and which grammaticalization theory is supposed to explain, are obvious facts of historical linguistics." However, there is disagreement between generative and cognitive approaches as to when and how such changes occur.

\section{Generative and cognitive approaches to grammaticalization}

Works pursuing the topic of grammaticalization from within generative framework include Haegeman (1985, 2012), Roberts and Roussou (2003), and Faarlund (2008). ${ }^{7}$ One mechanism commonly posited by generative linguists to explain language change is abrupt intergenerational reanalysis in language acquisition (Traugott and Trousdale 2010: 21).

A change is initiated when (a population of) learners converge on a grammatical system which differs in at least one parameter value from the system internalized by the speakers whose linguistic behaviour provides the input to the learners. As the younger generation replaces the older one, the change is carried through the speech community.

Roberts and Roussou (2003: 11)

This attempts to account for language change and at the same time preserve the homogeneity of idiolects, since change does not occur within an individual's grammar, but only between generations of speakers.

However, linguists coming from a cognitive perspective have questioned whether such an approach is workable in light of actual language data (Aitchison 2003: 737-740). ${ }^{8}$ For example,

\footnotetext{
${ }^{7}$ Compare the incorporation of reference to grammaticalization in the studies by Hill (2012), Manzini (2012), and Willis (2012). See Van Geldering (2011) for an overview of the relationship between grammaticalization theory and generative grammar as well as a sketch of several generative approaches to the topic. Kortmann (1997: 28-32) describes Haegeman's (1985) study as a pioneering effort to account for language change (specifically regarding adverbial subordinators) from within a generative framework.

${ }^{8}$ One observation Aitchenson makes here is that putative examples of homogeneity in an idiolect are only possible when the data is smoothed over to exclude certain elements, such as the difference between more formal and more colloquial usage, which varies in single individuals (cf. Hopper and Traugott 2003: 109, 128, 172). Fischer (2007: 67) makes a similar observation when she ntoes that the data used in generative approaches resemble "the written forms of language rather than the spoken. This is presumably because the written language looks more logical,
} 
take the case of German weil developing from a temporal subordinator to a causal coordinator. ${ }^{9}$ In such a scenario, can we suppose that those from the generation before the reanalysis occurred used weil exclusively as a temporal subordinator, but (some of) the subsequent generation used it exclusively as a causal coordinator? In such a situation, any utterance using weil in a way in which the temporal relation did not exactly correspond to a felicitous causal relation would result in unintelligibility between adjacent generations. Intergenerational communication in this scenario would presumably be just as intelligible as an English speaker trying to understand a translation of the German utterance discussed in Keller (1995: 22) in (3), not with its causal meaning, but with the original temporal meaning of weil as in English while, since they would simply be the result of (presumably mutually intelligible) intergenerational reanalysis.

Er ist nach Hause gegangen, weil ich sehe seinen Mantel nicht
He is after house went because/while I see his coat not
mehr an der Garderobe.
further at the cloakroom
"He's gone home, because while I no longer see his coat at the cloakroom."

Of course, it would be hard to make sense of this, to say the least (not to mention the syntactic shift from an originally subordinating temporal clause with verb-final word order to a coordinating causal clause with verb-second word order). ${ }^{10}$ However, we do not see this sort of unintelligibility between adjacent generations (at least not for this reason!). For these reasons (among others), cognitive linguists find it hard to see how abrupt intergenerational reanalysis would actually work out. ${ }^{11}$

Alternatively, a cognitive approach to grammaticalization sees it as gradual and identifies the locus of change within the idiolect via, for example, the inferential processes of metonymic and metaphorical extensions, especially as articulated in the landmark works of Heine et al. (1991) and Hopper and Traugott ([1993] 2003). ${ }^{12}$ Once this perspective is entertained, idiolects themselves may be characterized by gradient continua and fuzzy boundaries, structured by prototypicality (Geeraerts and Kristiansen 2015: 371). To use the example of weil above, cognitively motivated processes invite interpretively enriched readings of temporal relations as causal relations via the post hoc ergo propter hoc ("after this, therefore because of this") line of reasoning which guides our causal inferences (Traugott 1985: 297; Kortmann 1997: 190;

\footnotetext{
uses complete sentences rather than half-finished ones and is relatively free of fuzziness and variation (in social and stylistic terms, since the written forms used are those of educated speakers) and hesitation phenomena." Additionally, Luraghi (2010: 359) seems to argue that an intergenerational mechanism would prove too much, explaining: "...following the child-based theory one might expect that features of baby talk to go into language change, which is patently not the case..."

${ }^{9}$ English while has developed a different extended use as a concessive. This extended use continues with the older temporal use.

${ }^{10}$ On this change from subordinate to coordinate clause order, see Hopper and Traugott (2003: 210-211). Compare the development of French car discussed in Evers-Vermeul et al. (2011: 457).

${ }^{11}$ Also see Bybee's (2010: 183-187) comments on invariant meaning hypotheses (cf. Kortmann 1997: 17-18).

${ }^{12}$ Much of this was anticipated in erlier work, even before "cognitive linguistics" emerged as an identifiable approach to language. For example, the foundation of such a cognitive approach to language change can even be found articulated in Weinreich et al. (1968: 156) when they write: "If we abandon the individual homogenous idiolect as a model of language we can suggest a more intelligible mechanism of transfer." They go on to propose a gradual view of grammarticalization with multidialectal speakers with heterogeneous systems within their linguistic competence. In fact, Ravid (1996: 118) specifically cites Weinriech et al. (1968) as the point of departure for a cognitive approach to language change.
} 
Haug 2008: 289-290; Degand 2009). Crucially, this is said to occur in the act of communication itself in which interlocutors are seeking the most relevant interpretations (Traugott 2010: 5556). Through entrenchment, these enriched readings become gradually semanticized. However, these older and newer uses persist side-by-side, resulting in polysemy within the idiolects of individual speakers. ${ }^{13}$

Thus, in summarizing the difference between generative and functional approaches to language change, Fischer (2007: 75) writes: "According to the generative model, all categories are discrete. The system is digital rather than analogue. Intermediate steps are therefore not considered possible, at least not at the level of the grammar. In the analogue grammaticalization model the categories are fluid, containing prototypical as well as peripheral members." ${ }^{" 14}$ While such deep-seated assumptions pose a formidable obstacle to compatibility between these two theories of language, linguists may be able to put such questions on hold and find common ground when approaching intergenerational corpora of ancient languages.

\section{Finding common ground}

The proposal here is that the above-mentioned differences between generative and cognitive approaches to polysemy and grammaticalization can be somewhat bypassed when it comes to the study of mutli-author and intergenerational corpora of ancient languages. The simple reason for this is that gathering a reasonably sufficient amount of data for the linguistic analysis of an ancient language requires consulting the work of multiple authors spanning many generations and will therefore inescapably include significant amounts of linguistic variation.

While this observation holds for a number of ancient languages, the language of the Hebrew Bible may be taken as an example of this par excellence, where linguists do not really have an option for strictly synchronic analysis of an ideal speaker in a homogenous speech community. The composition of the Hebrew Bible includes many authors, spans several centuries, includes the later editing of previously written material (e.g. the post-exilic community appropriating pre-exilic texts in the canonical form of the Psalms), contains linguistic updating on the one hand and archaisms on the other (Carr 2011: 125-132; Dresher 2012: 22; Rezetko and Young 2014: 111-112) ${ }^{15}$, and is simply too small to both isolate idiolects (even if that could be reliably done) and still have enough data from which to produce a reasonably complete grammatical treatment. Even when taken as a whole, "the vocabulary and idiomatic range of BH [Biblical Hebrew] must have fallen far short of the Hebrew potential of biblical times" (Ullendorf 1997: 9) and is therefore "clearly no more than a linguistic fragment" (ibid: 16). Thus, dividing it up even further into supposedly grammatically homogenous texts (an impossible task given its complex textual history) would only further limit its already limited witness to the language.

\footnotetext{
${ }^{13}$ Of course, this is not to suggest that all polysemy patterns within a speaker's idiolect always arise through their own inferential processes. Most of the semantic and functional potential of words may be simply learned through acquisition without the speaker ever going through, let alone being cognizant of, the inferential processes that led to their emergence. In fact, contrary to their own usage, speakers themselves may try to impose a static definition of words and constructions when reflecting on their meanings. The point being made here is that according to a cognitive model of language change, the genesis of change cannot be confined to intergenerational transitions. Rather, change takes place within idiolects and even includes invited inferences made by the speaker, making it impossible to relegate it to a passive process, which Traugott (2010: 55) calls "hearer/perception models".

${ }^{14}$ See Fischer (2007: 64-82) for an overview.

${ }^{15}$ Compare Kouwenberge's (2012: 445) comments on these features in the Enuma Eliš written in Standard Babylonian.
} 
Even those who advocate dividing up the language of the Hebrew Bible into so-called Early Biblical Hebrew and Late Biblical Hebrew are careful to acknowledge that "languages evolve gradually, and the division into just two corpora is certainly artificial to a certain extent" (Joosten 2016: 332; cf. Givón 2012). Therefore, the linguist is forced to treat many converging lects in order to engage in the grammatical analysis of the language in the Hebrew Bible. ${ }^{16}$ Similar comments would obtain for the study of Old Aramaic, Septuagint Greek, or any other ancient language for which we must compile variegated sources.

Thus, because such intergenerational corpora indisputably include genuine language change, they must also be characterized by grammatical polysemy. As Weinreich et al. (1968: 188) point out: "...all change includes variability and heterogeneity." And, because completely untangling the complex textual history of such corpora into discrete homogenous idiolects is impossible and would critically reduce the already limited language data, it would seem that those undertaking grammatical analysis are more or less bound to a study of the "corporalect" spanning many many generations. Certainly any analysis claiming to be representative of the language of the Hebrew Bible would include a very large number of lects indeed. As explained by Naudé (2012: 72), “...language variation always exists in a speech community, let alone a society; and a given language (viewed as a multilayered, complex system) is always in transition" (cf. Geeraerts and Kristiansen 2015: 370-371).

The payoff off from this is that linguists approaching the Hebrew Bible (or other ancient corpora with similar characteristics) either from generative or cognitive perspectives can both agree that the various elements of a grammar of the Hebrew Bible must be presented as polysemous, arranged along grammaticalization paths, and organized within a form's usage profile according to prototypicality. I will now briefly offer one example of how this perspective may help bridge the divide in disputes regarding the analyses of the grammar of the Hebrew Bible.

I will limit my comments to two scholars who have interacted with each other on the analysis of the Hebrew verbal system, one representing a generative approach and the other a cognitive approach as described above. I will also focus my brief comments on their analyses of just one of the verbal conjugations they treat, the Qatal. Cook (2012: 178) argues that the verbal forms of Biblical Hebrew changed according to the generative model sketched above. ${ }^{17}$ Because of this, he views the tense, aspect, and modality categories of Biblical Hebrew verbal forms " .... as discrete and their meanings invariable" (ibid: 180). Alternatively, Andrason (2011, 2012, 2013) takes the cognitive perspective sketched above which sees polysemy as a fundamental part of language due to its usage-based emergent properties at the idiolect level (cf. Andrason and Van der Merwe 2015). Setting aside for the moment these deeper theoretical disagreements, for the reasons outlined above, both models are compatible with the recognition of genuine polysemy

\footnotetext{
${ }^{16}$ I am using the term 'lect' following Geeraerts and Kristensen (2015: 366) as refering to "dialects, regiolects, national varieties, registers, styles, idiolects etc.).” Including epigraphic Hebrew, the Dead Sea Scrolls, and other periods of Hebrew, such as Rabbinic Hebrew, would increase the linguistic variation of the corpus even further. Of course, one may choose to confine their analysis to a single text within the Hebrew Bible. However, while such studies are indeed valuable, this approach would not eliminate the presence of multiple lects and would also not be able to serve as a representative sample of the language of the Hebrew Bible.

17 As Cook (2012: 268) states: "I have embraced the balanced view that individual grammars are static and therefore susceptible to synchronic analysis and that language change is strictly intergenerational." Thus, while not necessarily affirming generative grammar wholesale, Cook has certainly adopted its view of language change which views the idiolect as static. Compare Van der Merwe's (2014: 132) observation that Cook's analysis is a return to a generative-oriented approach, a characterization Cook (2016: 407) himself affirms.
} 
at the corpus level since it reflects the accumulation of various lects across speakers from many generations. Take for example the use of the Qatal verbal conjugation in the Hebrew Bible in example (4) from (Cook 2012: 78) showing that it can communicate quite different senses.

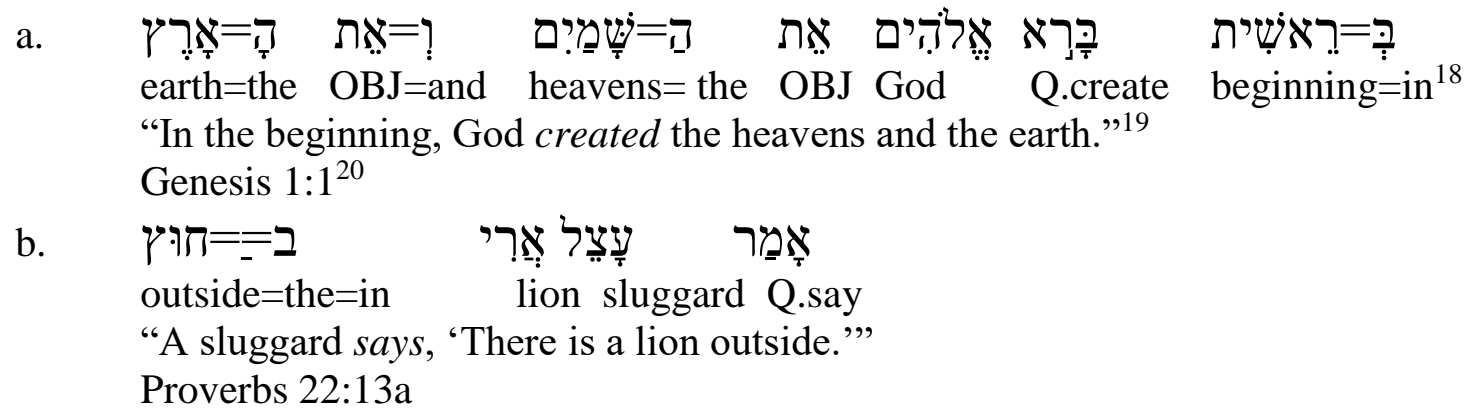

In (4), the Qatal form communicates a simple past action, but in (4), it communicates a present action. Andrason (2013: 113-120) explains such varying uses of this form by employing crosslinguistically pervasive grammaticalization paths, largely building on the seminal work of Bybee et al. (1994), among others. ${ }^{21}$ From this perspective, the input from which the Biblical Hebrew Qatal emerged regularly develops both past and present uses (among others). It is the retention of older uses alongside newer uses that results is synchronic polysemy throughout the Hebrew Bible.

Cook (2012: 208) also explains the diversity of the use of Qatal by employing grammaticalization paths based on Bybee et al. (1994), but presents an extremely coarsegrained path of development with different categories as follows: resultative in Common Semitic > perfect in West Semitic > perfective in Biblical Hebrew > simple past in Rabbinic Hebrew. What is crucial to note here is that the generative theory of language change to which he ascribes does not require large spans of perfect homogeneity (the corpus of Biblical Hebrew itself spanning many centuries), since, as described above, homogeneity is only posited at the level of the idiolect. When it comes to corpora such as the Hebrew Bible, proponents of polysemy need not appeal at all to cognitive approaches to language. The basic generative model of language change affirms this itself across such spans of a language. Indeed, the generative model must include the recognition that there is no decisive point at which a form immediately and completely jumps from one use to another across an entire language group. As summarized by Fischer (2007: 77):

There is no disagreement between formal and functional linguists that a change may be gradual on the level of the language output. This type of graduality of change is fully acknowledged: it involves the gradualness that can be observed in grammaticalization processes and in the diffusion of a change across a language community.

\footnotetext{
${ }^{18} \mathrm{Q}$ stands for the Qatal verbal conjugation, which is the focus of these examples and may be used as a past tense or present tense (among others), as glossed and translated.

19 Translations are the author's.

${ }^{20}$ This text is from the Biblia Hebraica Stugartensia.

${ }^{21}$ Compare Andrason's (2012: 151) use of these paths to also explain the polysemy of the Wayyiqtol conjugation. For a recent detailed discussion of these paths as applied to the Greek perfect tense form (analogous to the Hebrew Qatal), see Andrason and Locatell (2016: 24-31) and references there.
} 
To insist otherwise would be an unwarranted imposition on the generative model. Therefore, at some point between Cook's West Semitic and Rabbinic Hebrew stages on either side of Biblical Hebrew, there must certainly have been older and newer uses of the Qatal present within the language community represented by the grammar of Biblical Hebrew, even if he regards these as less (proto)typical (more on this in a moment). ${ }^{22}$

Thus, putting aside for the moment the fact that Cook and Andrason take incompatible approaches to the locus and mechanisms responsible for such diversity, there is no dispute between their respective models that such diversity really exists at the level of intergenerational corpora. That is, while Cook would argue that such a change arose in the process of language acquisition without disturbing the homogeneity of individual idiolects, and Andrason would argue for a process of change due to cognitively motivated processes originating within idiolects (even though the resulting polysemy patters can subsequently be learned "whole" by other speakers), their respective theoretical commitments allow them both to agree that a grammar of the Biblical Hebrew verbal system (which is necessarily based on a conglomerate of various lects) is characterized by grammatical polysemy.

To take this a step further, not only should both frameworks be able to whole-heartedly ascribe to grammatical polysemy at the corpus level, but even generative approaches should be able to affirm with cognitive approaches (such as that of Andrason) that such polysemy would have a principled structure. That is, each use would not be equally likely within the corpus. Rather, it would have a general likelihood within the corpus as a whole, and at a more fine-grained level, certain uses would be more likely than others in particular contexts. ${ }^{23}$ This means that each use of a form's polysemous potential can be organized quantitatively according to frequency as a measure of its centrality to the form's meaning. ${ }^{24}$ Additionally, given the fact that the grammaticalization paths resulting in such a polysemous usage profile are crosslinguistically pervasive, the uses themselves must have some underlying conceptual relationship to one another independent of the idiosyncrasies of Hebrew (cf. Hopper and Traugott 2003: 94-95; Traugott and Trousdale 2010: 32). ${ }^{25}$ This means that the uses within a form's polysemous potential would also be organized qualitatively according to grammaticalization paths. Crucially, these paths would structure both diachronic change and synchronic polysemy for those uses that coexist. What one ends up describing when accounting for such structure is in fact a prototype network in which the varying uses of a polysemous set are connected according to their conceptual relationship (as revealed by grammaticalization paths) and weighted in the

\footnotetext{
22 Cook (2016: 411) appears to intimate something along these lines when he uses overlapping paths of development to explain the preference for the Yiqtol to make general statements in Proverbs but preference for the participle (Qotel) to make general statements in Ecclesiastes. The implication is that a shift in usage is clearly discernable at the corpus level.

${ }^{23}$ Note Cook's (2012: 174) critique of those who do not account for such data.

${ }^{24}$ Of course, bare frequency may be misleading. What is termed contextual or relative frequency is a more precise measure (see further Locatell 2017: 120-126). For example, while the present use of the perfect tense form in the Greek New Testament has a very high bare frequency, this is almost exclusively confined to discursive texts and the verb oî $\alpha$ oida. This mitigates its impact on the prototypical meaning of the form. Alternatively, the present perfect use is virtually unrestricted by verb or text-type. Thus, while the bare frequencies of these two uses may be similar, the contextual or relative frequency of the present perfect use is far greater and therefore has a more salient impact on the prototypical meaning of the perfect tense form. See Andrason and Locatell (2016) for further details.

${ }^{25}$ See Cook's (2012: 206) description of the inferential process involved in reanalyzing a resultative as a perfect.
} 
overall usage profile according to "likelihood" of occurrence (i.e. prototypicality). ${ }^{26}$ Thus again, when approaching a corpus like the Hebrew Bible, it seems that both the generative linguist and cognitive linguist can agree that at the corpus level, grammatical forms will be characterized by polysemy and that the senses within their polysemous usage profiles will be organized relative to each other along grammaticalization paths, and weighted according to prototypicality (even if the underlying explanations for such phenomena differ). Perhaps we cannot find consensus in the debate over whether linguistic competence is characterized by static homogeneity or dynamic variation. But it becomes less relevant when approaching a corpus like the Hebrew Bible, the language of which is anything but homogeneous. ${ }^{27}$ In this space, perhaps we can come closer to the goal for corpus linguistic research envisioned by Glynn (2010: 9): "In such a scenario, with the old dialectic between Cognitive Linguistics and its Mentalist and Structuralist precursors forgotten, linguists would no longer need to identify themselves as one theoretical camp or another."

\section{Conclusion}

While I have only been able to make relatively brief and more or less tentative comments on topics of enormous breadth and depth, the compatibility between generative and cognitive approaches to grammatical polysemy in intergenerational corpora of ancient languages seems ripe with potential. Of course, there will always be a place for continuing discussion of theoretical differences. My comments here do not suggest any notion of solving the entrenched differences on either side. If this paper has at least highlighted the modest prospect of consensus regarding the presence of prototypically structured grammatical polysemy in ancient languages at the intergenerational corpus level (since this is essentially the only level available for study of such languages), then it will have accomplished its goal.

\section{References}

Aitchison, J. 2003. Psycholinguistic perspectives on language change. In B. D. Joseph and R. D. Janda (eds.) The handbook of historical linguistics. Malden, MA: Blackwell. pp. 736-743.

Andrason, A. 2013. El sistema verbal hebreo en su contexto semítico: una visión dinámica. Estella: Verbo divino.

Andrason, A. 2012. Grammaticalisation paths and non-equilibrium: Thermodynamics of the Biblical Hebrew verbal system. In D. Eades (ed.) Grammaticalisation in Semitic. Journal of Semitic Studies Supplement Series 29. Oxford: Oxford University Press. pp. 146-163.

Andrason, A. 2011. The Biblical Hebrew verbal system in light of grammaticalization: The second generation. Hebrew Studies 52: 19-51.

\footnotetext{
${ }^{26}$ While it makes sense that Cook (2012: 180) would distance himself from "any sort of prototype theory" at the level of the idiolect, his approach seems perfectly compatible with a prototype structured radial network of polysemous sets at the corpus level. Indeed, even his data itself appears to call for it if one is to present a grammar of the verbal system in the Hebrew Bible (cf. Van der Merwe 2014: 133). For a recent overview of prototype effects in grammar, see Taylor (2015).

${ }^{27}$ Similar comments can be made regarding the debate surrounding the Greek verbal system of the New Testament (see Andrason and Locatell 2016) and the infamously grammatically polysemous conjunction/complementizer/discourse marker כi in the Hebrew Bible (Locatell 2017).
} 
Andrason, A., and C. H. J. van der Merwe. 2015. The semantic potential of verbal conjugations as a set of polysemous senses: The "Qatal" in Genesis. Hebrew Studies 56: 71-88.

Andrason, A. and C. Locatell. 2016. The perfect wave: A cognitive approach to the Greek verbal system. Biblical and Ancient Greek Linguistics 5: 7-121.

Bybee, J. 2010. Language, usage, and cognition. Cambridge: Cambridge University Press.

Bybee, J. 2003. Cognitive processes in grammaticalization. In M. Tomasello (ed.) The new psychology of language: Cognitive and functional approaches to language structure. Vol. 2. Mahwah: Lawrence Erlbaum Associates. pp. 145-167.

Bybee, J., R. D. Perkins and W. Pagliuca. 1994. The evolution of grammar: Tense, aspect, and modality in the languages of the world. Chicago: University of Chicago Press.

Carr, D. M. 2011. The formation of the Hebrew Bible: A new reconstruction. New York: Oxford University Press.

Chomsky, N. 1965. Aspects of the theory of syntax. Special technical report, Massachusetts Institute of Technology. Research Laboratory of Electronics, no. 11. Cambridge: MIT Press.

Cook, J. A. 2016. Time to clarify. Hebrew Studies 57: 403-421.

Cook, J. A. 2012. Time and the Biblical Hebrew verb: The expression of tense, aspect, and modality in Biblical Hebrew. Linguistic studies in ancient West Semitic, v. 7. Winona Lake, IN: Eisenbrauns.

Degand, L. 2009. Describing polysemous discourse markers: What does translation add to the picture? In S. Slembrouck, M. Taverniers and M. Van Herreweghe (eds.) From will to well. Studies in linguistics offered to Anne-Marie Simon-Vandenbergen. Gent: Academia Press. pp. 173-183.

Dresher, E. B. 2012. Methodological issues in the dating of linguistic forms: Considerations from the perspective of contemporary linguistic theory. In C. L. Miller-Naudé and Z. Zevit (eds.) Diachrony in Biblical Hebrew. Linguistic studies in ancient West Semitic, v. 8. Winona Lake, IN: Eisenbrauns. pp. 19-38.

Elliger, K. and W. Rudolph (eds.). 1997. Biblia Hebraica Stuttgartensia. 5th corrected edition. Stuttgart: Deutsche Bibelgesellschaft.

Esseesy, M. 2010. Grammaticalization of Arabic prepositions and subordinators: A corpusbased study. Leiden: Brill.

Evans, V. 2014. The language myth: Why language is not an instinct. Cambridge: Cambridge University Press. 
Evers-Vermeul, J., L. Degand, L. Mortier and B. Fagard. 2011. Historical and comparative perspectives on subjectification: A corpus-based analysis of Dutch and French causal connectives. Linguistics 49(2): 445-478.

Faarlund, J. T. 2008. A mentalist interpretation of grammaticalization theory. In T. Eythórsson (ed.) Grammatical change and linguistic theory: The rosendal papers. Amsterdam: John Benjamins. pp. 221-44.

Fischer, O. 2007. Morphosyntactic change: Functional and formal perspectives. Oxford: Oxford University Press.

Geeraerts, D. and G. Kristiansen. 2015. Variationist linguistics. In E. Dąbrowska and D. Divjak (eds.) Handbook of cognitive linguistics. Berlin: Mouton de Gruyter. pp. 366-389.

Givón, T. 2012. Biblical Hebrew as a diachronic continuum. In C. L. Miller-Naudé and Z. Zevit (eds.) Diachrony in Biblical Hebrew. Linguistic studies in ancient West Semitic, v. 8. Winona Lake, IN: Eisenbrauns. pp. 39-60.

Glynn, D. 2010. Corpus-driven cognitive semantics: Introduction to the field. In D. Glynn and K. Fischer (eds.) Quantitative methods in cognitive semantics: Corpus-driven approaches. Berlin: Mouton de Gruyter. pp. 1-41.

Haegeman, L. M. V. 2012. Adverbial clauses, main clause phenomena, and composition of the left periphery. Oxford studies in comparative syntax; Cartography of syntactic structures, v. 8. Oxford: Oxford University Press.

Haegeman, L. M. V. 1985. Subordinating conjunctions and $\overline{\mathrm{x}}$-syntax. Studia Germanica Gandensia 2: 1-42.

Haug, D. 2008. From resultatives to anteriors in ancient Greek: On the role of paradigmaticity in semantic change. In T. Eythórsson (ed.) Grammatical change and linguistic theory: The Rosendal papers. Amsterdam: John Benjamins. pp. 285-305.

Heine, B., U. Claudi and F. Hünnemeyer. 1991. Grammaticalization: A conceptual framework. Chicago: University of Chicago Press.

Hill, V. 2012. A main clause complementizer. In L. Aelbrecht, L. M. V. Haegeman and R. Nye (eds.) Main clause phenomena: New horizons. Linguistik aktuell, Bd. 190. Amsterdam: John Benjamins. pp. 279-295.

Hopper, P. 2012. Emergent grammar. In J. P. Gee and M. Hanford (eds.) The Routledge handbook of discourse analysis. London: Routledge. pp. 301-314.

Hopper, P. 1987. Emergent grammar. In J. Aske, N. Beery, L. Michaelis and H. Filp (eds.) Proceedings of the thirteenth annual meeting of the Berkeley Linguistics Society: February 1416, 1987: General session and parasession on grammar and cognition. Berkeley: Berkeley Linguistics Society. pp. 139-157. 
Hopper, P. and E. C. Traugott. 2003. Grammaticalization: Second edition. Cambridge: Cambridge University Press.

Joosten, J. 2016. Diachronic linguistics and the date of the Pentateuch. In J. C. Gertz, B. M. Levinson, D. Rom-Shiloni and K. Schmid (eds.) The formation of the Pentateuch: Bridging the academic cultures of Europe, Israel, and North America. FAT v. 111. Tübingen: Mohr Siebeck. pp. 327-344.

Keller, R. 1995. The epistemic weil. In D. Stein and S. Wright (eds.) Subjectivity and subjectivisation: Linguistic perspectives. Cambridge: Cambridge University Press. pp. 16-30.

Kortmann, B. 1998. Adverbial subordinators in the languages of Europe. In J. van der Auwera and D. Ó. Baoill (eds.) Adverbial constructions in the languages of Europe. Berlin: Mouton de Gruyter.

Kortmann, B. 1997. Adverbial subordination: A typology and history of adverbial subordinators based on European languages. Berlin: Mouton de Gruyter.

Kouwenberg, N. J. C. 2012. Diachrony in Akkadian and the dating of literary texts. In C. L. Miller-Naudé and Z. Zevit (eds.) Diachrony in Biblical Hebrew. Linguistic studies in ancient West Semitic, v. 8. Winona Lake, IN: Eisenbrauns. pp. 433-451.

Lichtenberk, F. 1991. Semantic change and heterosemy in grammaticalization. Language 67(3): 475-509.

Locatell, C. 2017. Grammatical polysemy in the Hebrew Bible: A cognitive linguistic approach to Doctoral dissertation. Stellenbosch: Stellenbosch University.

Luraghi, S. Causes of language change. In S. Luraghi and V. Bubenik (eds.) The Bloomsbury companion to historical linguistics. London: Bloomsbury. pp. 358-370.

Manzini, M. R. 2012. The status of complementizers in the left periphery. In L. Aelbrecht, L. M. V. Haegeman and R. Nye (eds.) Main clause phenomena: New horizons. Linguistik aktuell, Bd. 190. Amsterdam: John Benjamins. pp. 297-318.

Naudé, J. A., 2012. Diachrony in Biblical Hebrew and a theory of language change and diffusion. In C. L. Miller-Naudé and Z. Zevit (eds.) Diachrony in Biblical Hebrew. Linguistic studies in ancient West Semitic, v. 8. Winona Lake, IN: Eisenbrauns. pp. 61-81.

Nerlich, B. and D. D. Clarke. 2003. Polysemy and flexibility: Introduction and overview. In B. Nerlich, Z. Todd, V. Herman and D. D. Clarke (eds.) Polysemy: Flexible patterns of meaning in mind and language. Berlin: Mouton de Gruyter. pp. 3-30.

Ramat, A. G. and C. Mauri. 2011. The grammaticalization of coordinating interclausal connectives. In H. Narrog and B. Heine (eds.) The Oxford handbook of grammaticalization. Oxford: Oxford University Press. pp. 656-667. 
Ravid, D. 1998. Cost in language acquisition, language processing and language change. In E. H. Casad (ed.) Cognitive linguistics in the redwoods: The expansion of a new paradigm in linguistics. Berlin: Mouton de Gruyter. pp. 117-146.

Roberts, I. G., and A. Roussou. 2003. Syntactic change: A minimalist approach to grammaticalization. Cambridge: Cambridge University Press.

Rezetko, R. and I. Young. 2014. Historical linguistics and Biblical Hebrew: Steps toward an integrated approach. Atlanta: SBL Press.

Taylor, J. R. 2015. Prototype effects in grammar. In E. Dąbrowska, and D. Divjak (eds.) Handbook of cognitive linguistics. Berlin: Mouton de Gruyter. pp. 562-579.

Traugott, E. C. 2010. (Inter)subjectivity and (inter)subjectification: A reassessment. In L. Vandelanotte, H. Cuyckens and K. Davidse (eds.) Subjectification, intersubjectification and grammaticalization. Topics in English linguistics, v. 66. Berlin: Mouton de Gruyter. pp. 29-71.

Traugott, E. C. 1985. Conditional markers. In J. Haiman (ed.) Iconicity in syntax. Amsterdam: John Benjamins. pp. 289-307.

Traugott, E. C. and G. Trousdale. 2010. Gradience, gradualness and grammaticalization: How do they intersect? In E. C. Traugott and G. Trousdale (eds.) Gradience, gradualness and grammaticalization. Amsterdam: John Benjamins. pp. 19-44.

Ullendorff, E. 1977. Is Biblical Hebrew a language? In E. Ullendorff (ed.) Is Biblical Hebrew a language?: Studies in Semitic languages and civilizations. Wiesbaden: Harrassowitz. pp. 317.

Van der Merwe, C. H. J. 2014. Time and the Biblical Hebrew verb. The expression of tense, aspect, and modality in Biblical Hebrew. Linguistic studies in ancient West Semitic, v. 7, J. A. Cook: book review. Journal of Northwest Semitic Languages 40(1): 131-135.

Van Gelderen, E. 2011. Grammaticalization and generative grammar: A difficult liaison. In B. Heine and H. Narrog (eds.) The Oxford handbook of grammaticalization. Oxford: Oxford University Press. pp. 43-55.

Weinreich, U., W. Labov and M. I. Herzog. 1968. Empirical foundations for a theory of language change. In W. P. Lehmann and Y. Malkiel (eds.) Directions for historical linguistics. Austin: University of Texas Press. pp. 95-195.

Willis, D. 2012. A minimalist approach to Jespersen's Cycle in Welsh. In J. Dianne, J. Whitman and A. Garrett (eds.) Grammatical change: Origins, nature, outcomes. Oxford: Oxford University Press. pp. 93-119.

Wulff, S. 2010. The compositionality of English V NP-idioms. In D. Glynn and K. Fischer (eds.) Quantitative methods in cognitive semantics: Corpus-driven approaches. Berlin: Mouton de Gruyter. pp. 223-238. 